\title{
EDUCATION FOR LIBRARY, LAW LIBRARIANSHIP AND INFORMATION SCIENCE IN NIGERIA
}

\author{
Uwem Eteng \\ Nigerian Institute of Advanced Legal Studies. University of Lagos, Nigeria
}

\begin{abstract}
The cardinal ingredients of every educational process are information, knowledge and skills which have seen a greater convergence of ideas towards a better definition and become the hallmark of every profession. This paper examines these three concepts in the developments of Library and Information Science (LIS) education in Nigeria and the role of NIALS in producing subject specific professionals. Core competency of academic law librarians are accessed and as a way forward. Competence in adapting to current developments in information technology application, knowledge organization, processing and provision is suggested.
\end{abstract}

Key words: Library, Information Science, Education, Law Librarianship, Training, Professional Competence, Information Technology.

Cite this Article: Uwem Eteng, Education For Library, Law Librarianship and Information Science In Nigeria. International Journal of Library \& Information Science, 7(1), 2018, pp. 63-70.

http://iaeme.com/Home/issue/IJLIS?Volume=7\&Issue=1

\section{INTRODUCTION}

It is perhaps pertinent to draw or indicate the relationships between these concepts-information, knowledge and skills and scholars have synthesized the views of various authors in these areas.

Many definitions view information as knowledge derived from, as knowledge communicated or received indicating that knowledge is the systematic organization of information and concepts. Nzotta ${ }^{[1]}$, Eteng \& Opeke ${ }^{[2]}$ viewed information as mankind's accumulated knowledge derived from all subjects that could help its users to reduce their levels of uncertainty. This delineation of both concepts is instructive. Information once assimilated by individuals becomes personal knowledge and personal knowledge once incorporated into books, files, software, oral messages, etc serves as potential information.

Drucker ${ }^{[3]}$, Rasmus ${ }^{[4]}$ take the differentiation further in terms of knowledge applicability in a knowledge economy. They summarized that

For the intellectual, knowledge is what is in a book, but as long as it is in a book it is only information, if not mere data. Only when a man applies information to do something does it 
become knowledge. Knowledge like electricity or money is a form of energy that exists only when doing work. The emergence of the knowledge economy is not in other words, part of the intellectual history as it is normally conceived. It is part of the history of technology that recounts how man puts tools to work. When the intellectual say "knowledge", he thinks of something new. But what matters in the knowledge economy is that knowledge whether new or old is applicable.

From these positions, it is evident that the applicability of knowledge is the result of the acquisition of skills through the educational process. The educational process brings the candidate into contact with the avalanche of information available in a specific subject field. The distillation of information results also in the assimilation of information leading to improved knowledge of the subject field. Skill is achieved when the candidate develops the capacity to apply acquired knowledge into specific professional areas. To function as a medical doctor, for example, the medical school graduate must demonstrate acceptable standard of information knowledge and skill in handling medical problems in key area of medicine. The law school graduate also must demonstrate capacity to handle legal matters. The result of both medical and legal training is that their products are able to pursue careers in medical and legal professions respectively. In the same vein, the Nigerian Library and Information Science schools have been in the forefront of producing Librarians and Information Scientists for careers in libraries and other information institution of various types and categories. In view of air ret developments in these institutions where the products of the Library and Information Science Schools (LISS) work and advances in information handling and management; the critical challenge for LISS is to produce industry-compliant professionals in two areas of competence:

- Competence in subject service specialization and;

- Competence in adapting to current developments of information technology application, knowledge organization, processing and provision.

These will be the major thrust of this paper.

\section{EDUCATION FOR LIBRARY AND INFORMATION SCIENCE: A HISTORICAL PERSPECTIVE}

A historical perspective is certainly an ideal starting point for a discussion on the education for library an information science in Nigeria. This provides an overview of intervening developments over the years. The Universities of Ibadan and Ahmadu Bello could rightly be regarded as the forerunners of education for library and information science in Nigeria.

According to Edoka ${ }^{[5]}$

'The Ibadan library school started in 1959 as the Institute of Librarianship on the fourth floor of the University library. From this modest beginning the school which later became department of library studies and currently department of library, archival, and information studies, is now a component of the Faculty of Education',

But the foundation for the establishment of institute of librarianship could be traced to a UNESCO seminar in 1953. They had the foresight and ingenuity to deliberate and give opinion on the over-all implication of public library development. The seminar was of the opinion that training in professional library schools outside Africa would not provide a fully satisfactory alternative to properly organized professional library training on African ground. The report firmly recommended the establishment of a limited number of high quality library schools in Africa. This was a bold statement of intention."

It is evident that from the very beginning library and information education was aimed at domesticating professional training to suit the peculiar needs of libraries in Nigeria. A properly 
organized professional library training was considered appropriate for producing professionals who could address the realities of African problems. This same perspective was the catalyst for the evolution of library schools in Ahmadu Bello University Zaria in 1968 and Ibadan. However, other factors have contributed to the emergence of other library schools in Nigeria.

- The establishment of more educational institutions especially at the tertiary level after the end of the civil war in 1970.

- Creation of more states in the 1990s leading to the establishments of state universities in various parts of the country

- The approval of the Federal Ministry of Education allowing private individuals to establish polytechnics, colleges of education and Universities.

Since these institutions cannot do without librarians, the need to produce more professionals was a corollary development.

\section{EDUCATION FOR LIBRARY AND INFORMATION SCIENCE: PROGRAMME PERSPECTIVE}

The initial training for librarianship at the Institute of Librarianship Ibadan was built on two programmes. The first was for University graduates who desired to pursue a career in librarianship. Initially this strands of the programme ultimately produced postgraduate Diploma in librarianship holders. The other programme which provided opportunity for practicing nongraduate library staff to qualify as career librarian followed the curricula of the library association of London. Edoka ${ }^{[5]}$ observes that the institute prepared its students for associateship of (British) Library Association (BLA) examination with the following courses.

- Bibliography

- Cataloguing and classification

- Library organization (administration) and

- Literature of a social subject.

Over the years however, the programme of training for BLA qualification was abandoned and a Diploma in librarianship at the Ibadan school produced graduates of the paraprofessional cadre. One key advantage of the postgraduate Diploma graduate was that it helped produce librarians with subject background, example(Geography, Sociology) or science background (e.g. Chemistry, Physics) or law background are well-suited for careers as social science, science and law Librarians respectively. Over the years also, the pro-graduate studies at Ibadan was replaced with masters in library studies (MLS).It is important to mention at this juncture that polytechnicand colleges of education initiated programmes in library education. The polytechnic programmes essentially produced holders of national and higher national diplomas in librarianship. These are career paraprofessionals who function as library officers in most libraries. Over the years, government policy has diverted from the universities the responsibilities of Diploma training programmes. It is squarely invested on Nigerian polytechnics institutions.

The education for librarianship in Nigerian Colleges of Education has a completely different goal to produce teacher- librarians for the nation's teeming secondary institutions. Trainees for careers in school librarianship pursue a kind of due programmesc-one in a teaching subject and the other in librarianship.

A wholly information science training program never emerged in Nigeria until the (ARCIS) African Regional Centre for Information Science was established at the University of Ibadan in the early 1990s. Currently, ARCIS runs programmes leading to master and doctorate degrees in Information Science Initially funded by Canada's International Development Research Centre (IDRC), ARCIS programmes are opened to candidates from other African countries. 


\section{EDUCATION FOR LIBRARY AND INFORMATION SCIENCE: PROFESSIONAL STATUS PERSPECTIVES}

Who is a librarian? Answer to this question may be many and varied but the crux of the matter deals with professional status. As Dada ${ }^{[6]}$ posited, the issue of recognition of librarianship as profession has crossed the line of controversy:

The question as to whether librarianship is a profession or not is not the issue here. The profession of librarianship in Nigeria has been given legal effect as per the provisions of librarians (registration, etc) decree No. 12 of 1995. The facts stand out that with the notable exploits of late John Harris (1903-1980) at the University of Ibadan and ever since the successful hosting of the UNESCO seminar on public libraries in African at Ibadan in 1953, the discipline of librarianship had maintained an effective posture of a full fledge profession manifesting virtually all the university accepted attributes of a profession properly so called.

The Librarians' Registration, Council rests on the Council five major responsibilities of which four are relevant to the issue of professional status:

- Determining who librarians are for the purpose of this decree.

- Determining what standards of knowledge and skill are to be attained by persons seeking to become registered as librarians ("in this decree referred to as the profession") and reviewing those standards from time to time as circumstances may required.

- Securing in an accordance with the provisions of this decree, the establishment and maintenance of a register of person entitled to practice the profession and the publication, from time to time, of lists of such persons.

- Maintaining discipline within the profession in accordance with this decree

The determination of who a librarian is, is related to the standard of knowledge and skills to be attained by persons seeking to register as a librarian. While a minimum of a first degree is recommended as entry point into the professional status, the issue of relevant experience is still debatable. Perhaps induction courses for bachelor degree holders in librarianship may be an appropriate step forward while masters in librarianship graduates who entered from other non-librarianship degrees may also require induction programmes.

Diploma and NCE holders face a peculiar professional dilemma as they cannot be categorized as librarians and there is currently no association or society of information scientists. Libraries at the moment remain the greatest employers of this particular group of information professionals. Those of them with relevant work background may therefore be under necessary inductive processes leading to registration as librarians.

\section{LIBRARY AND INFORMATION SCIENCE EDUCATION AND LAW LIBRARIANSHIP}

One of the emerging issues of LIS education in Nigeria is challenge to produce specialized professionals that could provide leadership in specific subject areas like law, medicine, etc. Argument against one design of developing a programme specific to law rests on proposition that other disciplines and professions can also agitate for discipline specific LIS programmes. Evidently the peculiar service disciplines have led librarians to come together to discuss unique challenges and develop professional associations such as Association of Law Librarians, Association of Medical Librarians etc. With these disciplines and developments, the fashioning of programmes in Nigerian LIS that will produce leading discipline - specific professionals is imperative. It is only logical that there are now emerging training institutions where their products are working.

Perhaps, Nigerian Institute of Advanced Legal Studies (NIALS), the apex law institution in Nigeria can collaborate to fashion out a unique educational apparatus in law librarianship. The 
programmes should aim at developing general competencies in librarianship and subject competencies in law. The law competencies will introduce the trainee to the legal bibliographies, special library courses, the legal system and its terminologies, law research with partial participation in law school courses, noter-up services, legal indexing, cataloguing and classification of legal materials. This offering will also include adherence to regular feature in Law Library Journal, the major of which is floated by NIALS titled NIALS Journal of Law Library and Information Technology (NJOLLIT) since 2013.This way Nigerian library and information science educational institutions will be responding to growing needs of specialist law librarians in positive ways.

\section{ACADEMIC PROGRAMMES IN LAW LIBRARIANSHIP}

The redesign of library school curricula mentioned in the above paragraph will aim at addressing three areas of competencies - general competencies and subject competencies, a third dimension is IT competencies. A further elaboration of these three critical areas is necessary.

\section{General Competencies}

Librarianship is a profession in its own right. Professional standards ethics and practice are discernable attributes of all leading professions. The general competencies stream of the curricula for law librarianship will significantly impact on the skills of lawyers and other professions' degree holder who are contemplating a career in law librarianship. For example, the American Association of Law Librarians ${ }^{[7]}$ suggests that this stream should cover:

- Reference and Research Services

- Library Management

- Collection Management; and

- Organization and Classification

The goal of the reference and research sub-stream will develop the trainee law librarian's competencies on how to:

Provide information to meet specific needs of the client. Since law librarians work in different legal information settings like academic, court, private law firms, belong to associations both in corporate and government institutions, international organizations and research bodies- the need to be competent in addressing users' information needs based on these diversities become very compelling professional imperative.

Design and install selective dissemination of information service. The assumption that generalized information series will meet the need of everybody is like believing that a single bullet will get many birds in the forest. When information service is targeted to a segmented group in a profession, its utility value increases. The art of designing such a service is an art that must be learnt.

Analyze and evaluate information sources

Develop and deliver new services to meet the changing needs of legal professionals

Design marketable information products and services

Use multimedia tools and services for information referencing; and

Contribute to legal research methods and projects

The American Association insists that principles of management and organizational behaviour must be part of all graduate library school programs. Specifically, law librarians must learn techniques for managing personnel and resources, measuring and valuating resources, library services and implementing technology based solutions to library management problems. 
Organizational psychology, human resources as well as information resources are all critical to effective administration of law libraries.

Materials in a law library are as complex as the clientele system that uses them. The process of acquisition and domestication in the library is more specialized to meet quality legal research needs of their users. The whole scenario of collection management is becoming increasingly complex as the Law Librarian tries to understand the complex interplay of legal sources and the handling of print and electronic information resources. The collection sub-stream of the general competencies stream should address how to manage the evolving environment.

It is noteworthy that the interdisciplinary nature of law and the variety of formats of legal resources calls for both intellectual and physical organization. Intellectual organization deals with how to classify law materials into the various subjects of law so that related materials are located in the same place to make legal research efficient. Physical organization strategizes on how the multi-media blend of law materials are to be organized to find answers to legal problems.

\section{SUBJECT COMPETENCIES}

The subject competencies stream is relevant to trainee law librarians who do not have a background in law. They need courses that cover law themes such as the Nigerian Legal System; Legal profession and its terminology - the more complex the body of law the more highly specialized its jargon becomes, How does the law librarian work in the various legal subsystems if he does not have a global view of the legal system? How does he become more sophisticated as the language of law gets more specialized. How does he know the various law materials-law reports, case law status, Acts, transcripts gazettes; their sources and significance with this subject competence stream. Many law scholars seem to believe that the generalist law librarian does not really understand their information seeking behavior and needs. Hazelton ${ }^{[8]}$ suggests that the law librarian should become important link in the chain of access to information if he also brings the relevance of non legal information. Most lawyers are not trained in the art of non legal research but they need this knowledge as law gets so multidisciplinary in outlook. The merging of understanding between the seeker and service provider is important before the appropriate source is interfaced in a seeker/provider context. Ethical issues related to copyright and fair use should be property understood by the librarian. This will not only guide the librarian in service provision but will also provide knowledge of extent of use violation.

\section{STRATEGIES FOR IMPLEMENTING ACADEMIC LAW LIBRARIANSHIP PROGRAMME}

It has earlier been suggested that Nigerian Institute of Advanced Legal Studies (NIALS) could cooperate with Department of Library, Archival and Information Studies (LARIS) to run a postgraduate law librarianship programme. In this regard, NIALS is best suited to handle the subject competencies stream. In a three semester, eighteen-month postgraduate programme, the subject stream can be held at NIALS, while the general competencies programme could run at LARIS. The IT competencies stream should ideally be industry related practical attachment in an intensive IT-based information management environment. To give legal framework for such collaborative initiative, the appropriate portions of the law setting up NIALS may need to be amended through a sponsored bill at the National Assembly. 


\section{LIBRARY AND INFORMATION SCIENCE EDUCATION AND INFORMATION TECHNOLOGY}

Information technology intervention in all facets of knowledge management is the other emerging issue that education for library and information science must address. The school of information studies at the Syracuse University ${ }^{[9]}$ rightly indicated that:

"At the start on the $21^{\text {st }}$ century, librarians found their work situated at the forward of cultural and social transformation. Technology advances have redefined the information environment in ways that pose technical, intellectual and ethical challenging to the library profession, including the nature of presentation and archiving, issues of information access, intellectual property and fair use. The library profession is evolving, redefining itself to meet the challenges of the changing environment. In an era in which increasing sectors of economy are developed to information management, the librarians' task will be to translate profession's traditional values and expertise to meet the demand of the new environment."

To meet the demand of the new environment is a critical consideration. It is realizable if the library and information science educational institutions redesign their training programmes to incorporate information technology components. It amounts to a disservice to the library and information institutions and industries if products of LISS are not skilled IT users. That seems to be the status quo that must change

\section{INFORMATION TECHNOLOGY COMPETENCE}

The law librarianship of the future will be dominantly controlled by development in the information and communication technology sector. The law librarian of the future therefore needs to be equipped on how to use ICT systems to serve his clientele. Areas for critical competence include computer literacy, database management skills, information and internet literacy.

\section{LIBRARY AND INFORMATION SCIENCE EDUCATION LOOKING AHEAD}

This concluding section reviews the future of library and information science education in Nigeria. Education for library and information science in Nigeria has undergone remarkable changes over the years. It has transformed from colonial installation to national institutions with emergence of strong professional associations like the Nigerian Library Association and the Nigerian Association of Law Libraries. The promulgation of Decree No. 12 of 1995 marked a watershed in the council in 2002 demonstrating a positive and pragmatic step in the journey to professional fulfillment. These foreground necessitate the following recommendation for the future of LIS education in Nigeria.

- Nigerian library and information science training institutions need to redesign their curricula to meet present needs and future challenges of the library and information institutions in Nigeria. A strong IT competence is essential to produce professional who are relevant to library institutions and information industry environments. Moreover, training that leads to the emerging of competent professionals in disciplines such as law is necessary. Collaborative initiative between well-staffed institutions like NIALS and LARIS Department of the University of Ibadan should be explored.

- The Librarians Registration Council of Nigeria has a prominent role to play in upgrading the skills and knowledge of all those who seek to become chartered librarians. It should articulate a compulsory continued education programmes to consistently upgrade the skills of even registered librarians. 


\section{CONCLUSION}

It is necessary to recommend a self-skill improvement programme for the forward-looking professional. Those who find themselves in law librarianship must master legal information resources, services and terminologies to increase their usefulness in the legal information service environment; Computer, IT and Internet literacy can be acquired through self-education. With these recommendations properly addressed, the future is bright for both LIS educational institutions and the law librarianship profession.

\section{REFERENCES}

[1] Nzotta, B.C. (1993) Developing a responsive legislative library and information service. In:Ezeila L.O.and Hindu,J.T.(2016) Use of information by researchers: A case study of National Veterinary Research Institute. Vom. Journal of Research in Humanities and Social Science. Vol.4, Issue 8

[2] Eteng, U \& Opeke, R (2015) Information accessibility and use as correlates of women political participation in the Niger Delta region of Nigeria. Journal of Psychology and Behavioural Sciences. Vol.4(1)

[3] Drucker, P.F. (2005) The essential Drucker: The best sixty years of Peter Drucker essential writings on knowledge management. Collins Buiseness Essentials. Harper Business

[4] Rasmus,D.W. (2012). What is an information worker? Available at: http://www.seriousinsight.net/what-is-an-information-worker/

[5] Edoka, 1 (2010) Future prospects. In: Olanlokun, S.O. and Salisu, T.M. (ed.).Libraries and Librarianship in Nigeria. A festschrift for Ezekiel.

[6] Dada, T.O. (2011). Law librarianship and legal research in the digital age. http://nialsnigeria.org/pub/lawlibrary.pdf

[7] American Association of Law Librarianship. (Fall 1993) AALL Guidelines for Graduates Programmes in Law Librarianship. Library Trends 93.

[8] Hazelton, P. Education for law librarians. Available at: https://www. Lib.law.washington.edu.

[9] Dr. Harish Kumar Sahu, A Bibliometric Analysis of Research Contribution in PEARL: A Journal of Library and Information Science, 2012-2016. International Journal of Library \& Information Science, 6(2), 2017, pp.26-33.

[10] Dr. Santu Ram Kashyap, A Bibliometric Study of International Research Journal of Library and Information Science Period 2011 - 2014. International Journal of Library \& Information Science, 6(5), 2017, pp. 113-121.

[11] Dr. Harish Kumar Sahu, A Bibliometric Analysis of Research Contribution in PEARL: A Journal of Library and Information Science, 2012-2016. International Journal of Library \& Information Science, 6(2), 2017, pp.26-33.

[12] Dr. Santu Ram Kashyap, A Bibliometric Study of International Research Journal of Library and Information Science Period 2011 - 2014. International Journal of Library \& Information Science, 6(5), 2017, pp. 113-121.

[13] School and Information Studies, University of Syracuse (2002) Third Annual $21^{\text {st }}$ century Librarian Award: recognizing librarians work in shaping the Information environment Syracuse University School of Information Studies. New York. 